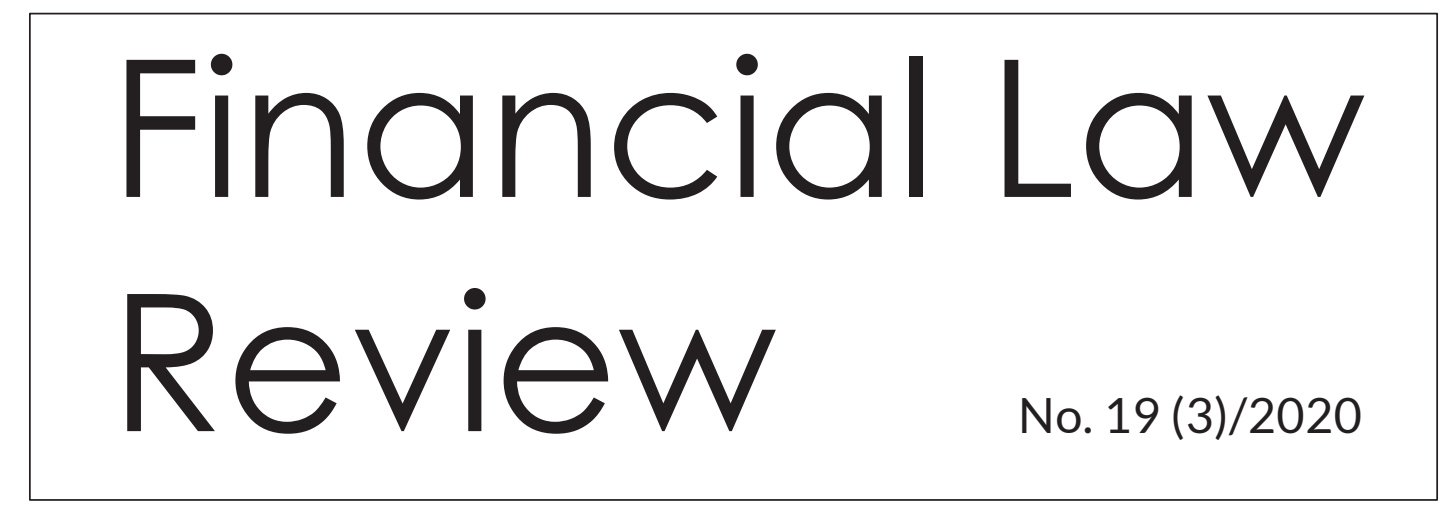

UNIVERSITY OF GDAŃSK • MASARYK UNIVERSITY • PAVEL JOZEF ŠAFÁRIK UNIVERSITY • UNIVERSITY OF VORONEZH http://www.ejournals.eu/FLR

SVEtLANa Mironova*

\title{
FINANCIAL AND LEGAL MECHANISMS FOR MUNICIPAL ENTITY TRANSFORMATION: EXPERIENCE OF RUSSIA AND OTHER COUNTRIES
}

\begin{abstract}
The amalgamations of municipalities take place in many countries, including Russia. One of the main reasons for this association is the possibility of solving the financial problems of small municipalities with its help, and increasing the efficiency of the use of budget resources. Does the amalgamation of municipalities achieve these goals? The foreign practice of several decades shows that not always after the merger budget funds begin to be spent more efficiently. Russian practice is not so long yet, but now analysis of budget data (for example, alignment of budgetary provision) shows that such conclusions can also be made in Russia. However, this requires a study of the financial security of the newly created municipalities for several years.

The article studies such important areas as the financial reasons for the transformation of municipalities; financial support of merging municipalities from higher budgets in order to ensure all territories of municipalities that are included in the newly created municipality; financial and legal consequences of such an association, i.e. whether it is really effective, as was stated when deciding on the association; alignment of budgetary provision of municipalities.

* Candidate of juridical sciences, Associate Professor, Department of entrepreneurial and financial law, Volgograd Institute of Management - branch of the RANEPA, Gagarina street, 8, Volgograd, 400131, Russia. Specialist in the field of financial law, research interests include financial and legal status of municipalities. Author of more than 130 publications, including monographs, textbooks. Member of the Public Chamber of Volgograd. As the Director of the legal clinic, she carries out activities on legal education of various categories of citizens and provides free legal assistance Contact e-mail: smironova2017@gmail.com
\end{abstract}


It is concluded that it is necessary to consolidate the principle of guaranteeing a municipality in Russian legislation at the federal level if it amalgamates with other municipal entities with financial support at a level not lower than that which it had before the merger.

The study results can be used to improve Russian legislation regarding the financial support of municipalities in the process of combining them.

Key words: local self-government, municipalities, municipal amalgamation, fiscal equalization, financial support, interbudgetary transfers, budget reduction

JEL Classification: $\mathrm{H} 71, \mathrm{H} 72, \mathrm{H} 77$

\section{Introduction}

The number of municipalities in Russia has declined significantly over the past few years. We are talking about the unification of urban and rural settlements in urban districts, and their connection with municipal areas. One of the main reasons for the enlargement of municipalities is the economic reason, the lack of their own financial resources in the settlements, primarily to address local issues. The rationale for the association is such factors as reducing the cost of maintaining local governments, eliminating duplicate municipal institutions, consolidating revenue in a single-center, and increasing the efficiency of using the municipal property. At the same time, it should be recognized that in some cases the unification of municipalities took place formally, without taking into account the principles of local self-government and ensuring the accessibility of local authorities for residents of municipalities, which predetermined the emergence of a new type of municipal formation - municipal districts. Meanwhile, there are still no exact answers as to how much the financial component is decisive in deciding on the merger of municipalities and whether the consolidation of municipalities leads to financial efficiency for the budget.

The article aims to disclose the financial reasons for the transformation of municipalities and the financial support of merging municipalities from higher budgets to ensure all territories of municipalities are included in the newly created municipality. It should be ascertained whether the amalgamation of municipalities is as financially effective as it is stated as the main argument of such a union, and also whether the amalgamation of municipalities affects the equalization of budgetary provision.

A comprehensive study of these issues in the Russian financial and legal science has not been conducted. Certain aspects of this topic are reflected in the works of Russian scientists. It will 
allow us to consider the financial and legal mechanisms for the transformation of municipalities comprehensively.

Abroad there are the same problems associated with the enlargement of municipalities since the processes of transformation of municipalities have been taking place in many countries for decades. In this regard, the international experience is of interest to scientific understanding in order to use it in Russian practice. Some aspects of this topic were reflected in the works of Franzke J., Kuhlmann S., Haug P., Illy A., Fox WF, Reingewertz Y., Rösel F., Gurley T., Fritz, B., Feld, LP, Seyfried M., Siegel J. Wirkungen von Gebietsreformen, Tavares, A. and several others. Certain aspects of this topic are reflected in many works (Bochkareva, Kail, Kosinsky, Larichev, Markvart, Franzke, Mironova, Morozova, Peshkova, Sheveleva, Uksusov, Vasyanina and others).

Systemic analysis is the main method employed during this study. It allows us to regard various financial and legal aspects of the amalgamation of municipalities: financial reasons underlying the amalgamation, financial guarantees for newly created municipalities, and the fiscal capacity of municipalities created.

A comparative analysis made it possible to see how these processes occur in different countries and Russia, as well as to see how legislators approach the issue of financial support for the amalgamation processes in different regions and how the amalgamation practice is going.

\section{Transformation of municipal entities in Russia: trends of the recent years}

As of January 1, 2019, there are 21,501 municipalities in Russia, of which 1,731 are municipal districts, 1,490 urban settlements, 17,380 rural settlements, 611 urban districts, three urban districts with intracity divisions, 19 intracity districts, 267 intracity territories (intracity municipalities) cities of federal significance. This figure is not constant since the number of municipalities is continually changing, facilitated by various reasons.

In addition to the traditionally called economic reasons, the main ones also include negative trends in demographic development (extinction of villages and towns, population migration, depopulation of territories, etc.) and improving the system of public services. Beyond the scope of our study, there will be reasons that are not directly related to the financial issue. We should agree with the chairman of the State Duma Committee on the federal structure and issues of local self-government A. Didenko, replacing the economic development of municipalities with their territorial transformations is unacceptable. 
In 2003, there were 11,576 municipalities, but after the adoption of Federal Law No. 131-FZ, their number doubled. Simultaneously, municipalities were formed within the boundaries of previously formed administrative territorial units, without taking into account the economic component. We should agree with P. Kosinsky, who writes about two opposite directions of development of local self-government: "their unreasonable fragmentation, which entailed a significant increase in the number of municipalities, and their equally unreasonable enlargement" [Kosinsky 2015].

Due to territorial changes in the borders of Moscow and Moscow region, from July 1, 2012 (following the Decree of the Council of the Federation of the Federal Assembly of the Russian Federation of December 27, 2011, No. 560-SF), the number of municipalities in Moscow Region decreased, and the number of intracity territories increased in Moscow.

Signifi cant changes in the number of municipalities occurred in 2014. In connection with Russia's accession of two new constituent entities of the Russian Federation - Crimea and Sevastopol, the number of municipalities increased by 289. However, in 2014, the trend of unifi cation of municipalities (rural settlements) continued in some areas of Russia - Tambov, Tver, Tula, Kemerovo, the Republic of Mari El, the Republic of Mordovia, as well as in several other regions.

Of particular interest is Magadan region's experience, in which all municipal districts and settlements were transformed into urban districts, and as of January 1, 2018, only nine municipalities are operating - urban districts.

The unifi cation of settlements and municipal districts in urban districts also occurred in Tver, Nizhny Novgorod, and Sakhalin regions. In Sakhalin Oblast and Magadan Oblast, there were no other municipalities left except urban districts.

In Smolensk, Astrakhan regions, and several other regions, the unification of rural settlements is observed without changing the type of municipality.

In 2018, the unifi cation of municipalities continued. For example, in Perm Territory as a result of the union of administrative centers with municipal districts' settlements, new urban districts appeared - Gremyachinsky, Gornozavodsky, Kizelovsky, Krasnokamsky, Okhansky, and Tchaikovsky. The unifi cation of municipalities in the Primorsky Territory is planned, the territorial reform of municipalities in Moscow region is going on.

In general, over 12 years, the number of municipalities has decreased by only $10.3 \%$, i.e. such a reduction cannot be significant. 
At the same time, many regions should be mentioned in which the territorial reform of local selfgovernment took place, which led to a significant reduction in the number of municipalities. In this case, two main trends can be distinguished: 1) the unification of rural settlements without changing the type of municipality; 2) the union of municipalities, urban and rural settlements into urban districts. In the first case, Kostroma region should be named among the leaders of the association (from January 1, 2010, to January 1, 2018, the number of rural settlements decreased from 261 to 134, which amounted to 48.7\%, i.e. almost twice); Kursk region (from January 1, 2010, to January 1, 2018, the number of rural settlements decreased from 480 to 295 , which amounted to $38.5 \%$ ).

In the second case, among the leaders of the association there can be distinguished Moscow region (from January 1, 2010 to January 1, 2018, the number of rural settlements decreased from 193 to 94 , which amounted to $51.3 \%$, i.e. the number of rural settlements decreased by more than half ; the number of municipal districts decreased from 36 to 16, which amounted to $55.6 \%$, i.e. the number of municipal districts more than halved; the number of urban districts increased from 38 to 51), Kaliningrad Oblast (from January 1, 2010 to January 1, 2018 , the number of rural settlements decreased from 47 to 4 , which amounted to $91.5 \%$, i.e., a decrease of 11.75 times (!); the number of urban settlements decreased from 19 to 6 , which amounted to $68.4 \%$, and the total number of settlements decreased by 6.6 times; the number of municipal districts decreased from 15 to 3 , which amounted to $80 \%$, or decreased by 5 times; the number of urban districts increased from 7 to 19), Stavropol Territory (from January 1, 2010 to January 1, 2018, the number of rural settlements decreased from 281 to 166, which amounted to $40.9 \%$; the number of urban districts increased from 1 to 17), Nizhny Novgorod region (from January 1, 2010 to January 1, 2018, the number of rural settlements decreased from 336 to 275 , the number of urban districts increased from 4 to 14 , i.e. 3.5 times), Magadan Oblast (municipal districts and settlements were completely liquidated, transformed into urban districts, in general, the number of municipalities decreased by 5.4 times).

The data presented show that currently in Russia there are actively ongoing processes of amalgamations of municipalities. Thus, the all-Russian trend in this direction is visible. The emergence in Russia of a new type of municipality - the municipal district - will lead to the continuation of this trend. Municipal districts will replace urban districts when merging municipalities. At the same time, the financial interests of abolished municipalities and residents of these territories should not deteriorate. 


\section{Foreign and Russian experience in uniting municipalities and their financial implications}

The process of transforming municipalities (to a greater extent, their unification, and consolidation) is inherent not only in Russia but also in foreign countries.

As noted in literature, community enlargement over the past 15 years has been planned or implemented in whole or in part in most OECD countries [Markvart, Franzke 2017: 43]. There are no uniform models and methods by which the territorial organization of local self-government is carried out in different countries. Nevertheless, the reasons for such transformations are the same as in Russia - low fi nancial independence, difficulty in providing services to the population, respectively, one of the arguments in support of community unif cation is "cost savings in the production of public services" [Markvart, Franzke 2017: 43].

The experience of Finland in uniting municipalities is interesting. The reform of the communes began in 1960-1970, it was because "the municipal structure with the predominance of small communes began to be regarded as complicating the implementation of the public functions of communes as mechanisms for the provision of equitable services"; "the requirements of residents of municipalities regarding the services offered to them increased"; thus "it is diffcult to organize the provision of a small commune sufficient services, especially in the increasingly difficult economic conditions" [Skorobogatov, Makarov 2011: 11, 13-14].

In Canada, the enlargement of municipalities has been carried out since 1995 and affected several territories [Larichev 2018: 353]. A. Larichev specifies many problems that have not been resolved in connection with the enlargement of Canadian municipalities, for example: "Data on the city of Toronto indicate not only the lack of budgetary savings for the provision of local services obtained during the merger, but also an increase in costs due to the need for infrastructural alignment of the merged municipalities," in connection with which "consolidation cannot be considered as a panacea, ... it is necessary to study the applicability of such instruments as intermunicipal agreements" [Larichev 2018: 355-356].

In Norway, at the state level, the following municipal reform goals that related to the financial side were identified: accessibility and quality of services for the population; the formation of financially sustainable municipalities. Optimization of expenses on local governments is one of the critical factors at the beginning of reforms [Leontieva et. al 2016: 138]. 
In Germany, the rationale for the need for changes in the eastern lands is given arguments such as insufficient fi nancial equalization of municipalities, the unfortunate fnancial situation of communities, and the high credit debt of many municipalities [Markvart, Franzke 2017: 47].

The above examples show that in many states, one of the main reasons for the unification of municipalities is their insufficient financial support and the ability to use their amalgamations to make fi nancial management more efficient.

In Russia saving budget expenditures, equalizing budgetary provision, is indicated as an argument for the unification of municipalities in Russian regional programs. For example, the Concept of the development of local self-government in Kirov region for 2009-2012 even refers to specific results that can be achieved in connection with the transformations of the municipalities of the region: "to solve the problem of low budget profitability and low tax potential (the volume of tax and other revenues to budgets of all levels at per-capita below 2 thousand rubles)".

The concept of reforming the territorial organization of local self-government of Leningrad Region sets such goals as: «improving the balance of local budgets of settlements; saving of local budgets and increasing the financial security of rural settlements; reduction of financial costs for conducting elections to local government bodies of the region.»

One of the main reasons for unifying municipalities is often financial savings, the so-called economic effi ciency. This thesis seems highly controversial. Thus, German researchers, analyzing the impact of the reform on the territorial change of local self-government through such a parameter as economy / economic effi ciency (Wirtschaftlichkeit), concluded that its positive effect is controversial [Kuhlmann, Seyfried, Siegel 2017: 6].

Other authors note the absence of measurable indicators that would indicate increased efficiency in the unification of municipalities. They argue that community unification is not a guarantee of higher economic efficiency, and the assessment of municipal reforms does not confirm the expected saving effect. In some cases, the opposite is a noted effect in rising costs [Erhard, Haug, 2011: 355, Rösel 2017].

There are arguments in literature about the budgetary efficiency of unifying municipalities by reducing management costs (Kail, 2013), but at present there are no comprehensive studies in Russia that could confirm or refute the economic efficiency of combining municipalities. Thus, it seems necessary for the Russian practice to use the existing foreign experience to 
take into account those issues related to financial efficiency, achieving budget cuts (or rather lack thereof) that are set as the goals of the unification of municipalities.

In connection with the solution of this issue on a political plane, it is necessary, at least when unifying municipalities, to calculate the economic efficiency of such an association and provide municipalities with guarantees of maintaining budgetary resources at the same level as before the unif cation. It seems that such guarantees can be attributed to the guarantees of the municipality, included in its financial and legal status [Mironova 2012: 28-30]. It is especially necessary to consider this factor when the union of municipalities occurs not voluntarily, but by the initiative of the constituent entities of the Russian Federation.

The Russian Federation's constituent entities should not only fully ensure the financial component of the transformation of the municipalities, take most of the costs associated with this, but also guarantee the municipalities the same level of financial support as before the merger. Such guarantees of municipalities are comparable "by the presence of" responsibility "of the higher budget for balance, that is, adequate provision with sources of income, lower budgets" [Sheveleva 2015].

For example, in Germany, «the state of Brandenburg committed itself not only to incur all onetime expenses associated with territorial reforms but also pay off on all cash loans affected by the reform of the municipalities and provide special subsidies to compensate for additional financial burdens associated with the integration of cities into municipal areas (Saxony used the same measures during the municipal reform)» [Markvart, Franzke 2017: 46, 49].

In Norway, the national government guarantees compensation for the transitional period costs and the maintenance of gratuitous budget allocations to the combined municipalities in the same amount for 15 years [Leontieva 2016: 139].

In Finland, the state used the "carrot policy," providing financial support to the merged municipalities in subsidies. The amount of subsidies paid is directly dependent on the number of merging communes. For municipalities that are part of the new municipality at a later stage, but no later than 2012, lower subsidies have been established compared to the stage of 20082010. For municipalities created after the onset of 2013, the framework law does not provide for subsidies. The new municipality created during the merger has the right to receive full compensation over the next five years if its aggregate share decreases in comparison with the total share of state payments received by all municipalities before their merger [Skorobogatov, Makarov 2011: 65-66]. 
Because there is no national concept of territorial reform of local self-government in Russia that would provide for such financial mechanisms to support the transformation of municipalities, no regulatory acts are regulating these issues at the federal level. Let us consider how the issues of financial support for the unification of municipalities and, in general, the financial features of the transformation of municipalities are addressed at the regional level.

The main document, which is the legal basis for the transformation of the municipality, is the regional Law on the local self-government organization on the territory of a particular municipality. Such a law establishes the specifics of making decisions about the budget, making changes to them, compiling, reviewing, and approving reports on the execution of local budgets, both for newly created and reorganized municipalities. For example, Law of Moscow Region No. 1/2018-OZ "On the organization of local self-government in the territory of Mozhaisk municipal district" stipulates that "compilation, review, and approval of reports on the execution of local budgets of settlements and Mozhaisk municipal district for 2017 and in 2018 before the date of the formation of local authorities of Mozhaisk city district are carried out by local authorities of Mozhaisk municipal district. The preparation, review, and approval of reports on the execution of local budgets of settlements and Mozhaisk municipal district for 2017 and in 2018 from the date of formation of the local government of Mozhaisk city district are carried out by the local government of Mozhaisk city district separately for each settlement and Mozhaisk municipal district following the budget legislation of the Russian Federation. The compilation, consideration, and approval of reports on the execution of local budgets of settlements and Mozhaisk municipal district for 2018 are carried out by local authorities of Mozhaisk city district separately for each settlement and Mozhaisk municipal district by the budget legislation of the Russian Federation".

An analysis of the laws of Moscow Region on the creation of urban districts shows that they all contain similar norms regarding the regulation of budgetary and inter-budgetary relations of newly created and abolished municipalities. The formation of new budgets and the solution of other issues are carried out according to the Russian Federation budget legislation. The Budget Code of the Russian Federation does not contain any special rules establishing the features of budget relations in the event of a reorganization of municipalities. Such norms are enshrined in regional laws on intergovernmental relations, which provide appropriate measures to support newly formed municipalities. Thus, the Law of Moscow Region of October 22, 2010, No. 123/2010-OZ "On Inter-Budget Relations in Moscow Region" in Article 101 provided for the rules for the provision of subsidies to budgets of the newly formed (as a result of transformation) municipalities of Moscow Region. This article expired on October 26, 2017, according to the Law of Moscow Region of October 23, 2017, No. 177/2017-OZ. The law does 
not contain any other rules governing this issue. It seems that this approach of the legislator is not valid, because, for Moscow region, which is undergoing a large-scale reform to unite municipalities in urban districts, it is essential to provide support for such a reorganization.

In this regard, of particular interest is the Law adopted in Perm Territory of February 28, 2018, No. 191-PK "On financial support in connection with certain types of transformation of municipalities in Perm Territory." The Law regulates relations on the provision of budgets of the transformed municipalities of Perm Territory with other inter-budget transfers to compensate for the shortfall in budget revenues and the payment of cash benefits to persons who occupy separate municipal posts and municipal service posts.

Under Art. 3 of the Law, compensation for shortfalls is paid from the first year of execution of the unified budget of the transformed municipal formation. Compensation of lost income is paid before the next fiscal year. The amount of tax potential for the tax in the budget of the transformed municipality exceeded the amount of the tax potential of the municipalities involved in the formation of the transformed municipality determined for the base year. The amount of compensation for lost income is approved by the Law on budget of Perm Territory for the next fiscal year and planning period and is provided to the transformed municipalities budgets in the form of other inter-budget transfers that are inappropriate (subsidies).

The adoption of this Law should be evaluated positively. After adopting the Law on Proactive Budgeting, Perm Krai again shows the progressiveness of financial legislation and its focus on resolving issues related to the development of the region as a whole.

Thus, measures should be taken aimed at financial support of the newly created municipalities, for example, providing for a transitional period during which the adopted budgets of the municipalities are maintained until the end of the financial year. The experience of foreign countries shows that such a period can last longer, from 3 to 15 years, which is advisable to provide in the regional legislation as a mandatory guarantee of municipalities.

\section{Fiscal capacity equalization in amalgamated municipalities.}

Since the majority of municipal entities does not have financial independence and depend on higher budgets, forming the majority of the local budget through interbudgetary transfers, the literature suggests that one of the reasons for municipal amalgamation is fiscal capacity equalization [Kosinsky 2015: 6-10]. 
At present, in Russia there is a situation where the level of budgetary provision of different municipalities (urban districts, municipal regions, urban and rural settlements) is different. Thus, the goal of unification of municipalities can be including the equalization of their budgetary provision (or fiscal capacity equalization).

Despite the fact that the legislator fi xes the term "equalization of budgetary provision", the concept itself is not disclosed in a normative manner, and in addition to the term above one can find in the literature the concepts of "budget alignment", "financial alignment" [Morozova 2016].

According to O. Morozova, "financial alignment is both a system of norms regulating the distribution of powers, income and expenses between different levels of power in a federative state and a system of legal relations formed between different levels of power in a federative state in the process of such distribution" [Morozova 2016: 203].

E. Bochkareva calls budget equalization one of the most advanced methods of budget regulation and defines it "as a process of bringing the amount of revenues of the respective budget to the amount of its expenditure commitments aimed at bringing together the capacities of the constituent entities of the Russian Federation and municipal entities to provide budget services to the population" [Bochkareva 2014: 72], and its signifcance "consists in the fact that in the process of applying its methods in order to achieve a balanced budget system in the Russian Federation, systemic interconnections of its hierarchically located elements are realized, social relations arise, which are formalized by means of budget law" [Bochkareva 2014: 73].

$N$. Sheveleva defines the essence of the phenomenon of "fiscal capacity equalization" in the Russian interpretation as creation of a system of legal regulation, which allows to financially ensure the execution of spending powers assigned to the appropriate level of public authority, through interbudgetary transfers - grants for fiscal capacity equalization [Sheveleva 2015: 32-44].

In H. Peshkova's opinion, the substantial features of the legal construction of the model of the budgetary structure of the Russian Federation do not fit into the absolute characteristic of any of the "models of financial equalization of budgets" formed in the world practice, which imply the corresponding inter-budgetary relations [Peshkova 2014: 362].

V. Uksusov relates guarantees of objectivity of the criteria for financial equalization to the legal guarantees of municipalities [Uksusov 2016: 45]. At the same time, the literature 
notes that "the system of equalizing budgetary provision fixed by law is not perfect from the point of view of fair distribution of financial resources between municipalities" [Vasyanina 2016: 364].

The newly created municipalities will allocate higher budgets to inter-budget transfers to equalize budgetary provision. Thus, the dependence of local authorities on higher authorities becomes more evident, which casts doubt on the constitutional principle of the independence of local self-government.

Thus, in fact, the system of fiscal capacity equalization is not conducive to the development of municipal entities, since municipalities have no incentive to develop local budget revenues (it could be described as a "life at someone else's expense" problem). At the same time, the importance of stimulating active fi nancial behavior of municipal entities was repeatedly highlighted [Morozova 2016, Peshkova 2014: 340].

Is it realistic to equalize fiscal capacity by combining municipal entities using this tool more efficiently? Articles 137 and 138 of the Budget Code of the Russian Federation provide for subsidies for fi scal capacity equalization of settlements (intra-city districts), and municipal districts (urban districts, urban districts with intra-city division).

It is necessary to note uncertainty of the norm of Article 137 (1) of the Budget Code of the Russian Federation in which it concerns city districts, as grants on the alignment of fiscal capacity equalization of urban districts are fixed by Article 138 of the Budget Code of the Russian Federation. It seems necessary to delete the words "urban districts" from paragraph 1 of Art. 137 of the Budget Code of the Russian Federation.

Art. 137-138 of the Budget Code of the Russian Federation provide for the possibility of replacing subsidies to equalize budgetary provision with additional standards for deductions to municipal budgets from personal income tax. It should be noted that the spread in standards by municipalities is quite large, which indicates a different level of their budgetary provision.

For example, additional standards for deductions to the budgets of urban (rural) settlements of the Moscow region instead of subsidies for equalizing the budgetary provision of urban (rural) settlements of Moscow region are set at $0.4 \%$ (urban settlement of Solnechnogorsk, Solnechnogorsk municipal region); 1.8\% (the rural settlement Kalinovskoye of Serpukhov municipal region, the urban settlement of Povarovo, Solnechnogorsk municipal region); $2 \%$ (rural settlement Bunkovskoye of Noginsky municipal district) to $49.7 \%$ (rural settlement 
Remmash of Sergiev Posad municipal region); 47\% (rural settlements of Kashinskoye, Spasskoye, Volokolamsk municipal district); 46.5\% (rural settlements of Vozdvizhenskoye, Voroninskoye, Klinsky municipal district).

The personal income tax deduction standards for urban districts and municipal districts are also very differentiated: from 1\% (Mytishchi); 1.7\% (Zvenigorod); 1.8\% (Balashikha); 2.1\% (Solnechnogorsk municipal district) to $85 \%$ (urban districts of Voskhod, Zaraysk, Ozyory, Lotoshinsky municipal district). At the same time, several urban districts with a high percentage of personal income tax deductions were created by conversion from municipal areas starting in 2015 (for example, Zaraysk, Shatura in 2017, Lakes, Silver Ponds, Shakhovskaya in 2015). Meanwhile, those with the status of ZATO (Voskhod) receive more significant support. Taldomsky municipal district, which also has a high deduction rate of $84.8 \%$ in 2018 , was transformed into Taldomsky urban district.

In general, the standards for deductions for urban districts and municipal areas are higher than those for settlements. We can conclude that for Moscow region such municipalities as urban districts are of higher priority than settlements, which is confirmed by the municipal reform that is being carried out in the Moscow region. Because the unification of municipalities takes place throughout Russia, it is advisable to conduct a similar study in other entities of the Russian Federation to find out how much the unification of municipalities affects the establishment of budgetary provision for certain types of municipalities.

\section{Conclusion}

One of the main reasons for the unification of municipalities is the financial reason and increase in the economic efficiency of local authorities. At the same time, the experience of foreign countries does not confirm the increase in financial efficiency as a result of the unification of municipalities.

The municipalities participating in the association must be provided with financial guarantees that will maintain the level of income and budgetary provision that existed before the association for a certain period of time. At the same time, higher budgets must finance all the merger procedures, so municipalities themselves should not bear the financial burden.

Although there are a large number of amalgamations of municipalities in Russia, there is currently no single concept at the federal level to provide financial support for such associations, as well as to establish financial guarantees for newly created municipalities. 
At the federal level, it is advisable to establish the general principle of guaranteeing financial support for a municipal entity at the same level if it is merged with other municipal entities.

The experience of Perm Territory can be used to address the issue of financial support for newly created municipalities in other regions of Russia. The main provisions of the Law adopted in Perm Territory of February 28, 2018, No. 191-PK "On financial support in connection with certain types of transformation of municipalities in Perm Territory" can be taken as a basis.

The result of the unification of municipalities is a change in the level of equalization of budgetary provision for certain types of municipalities. It can be assumed that a national policy aimed at enlarging municipalities will follow higher budget support for larger municipalities (urban districts and municipal districts).

\section{References}

Association of municipalities: the experience of Finland and the foundations of Russian legislation, ed. V. Skorobogatova, I. Makarova. St. Petersburg, 2011.

Bochkareva, E.: Pravovaya model' sbalansirovannoy byudzhetnoy sistemy v Rossiyskoy Federatsii (The legal model of a balanced budget system in the Russian Federation): dissertation. Moscow, 2014.

Erhard, C.: Kreisfusion hat Verwaltung offenbar teurer gemacht (Circular fusion has apparently made administration more expensive) URL: https://komunal.de/index.php/kreisfusion-teuer (accessed 14.09.2019).

Fox, William F., Gurley, T.: Will Consolidation Improve Sub-National Governments?, Washington, 2006.

Fritz, B., Feld, L.: Common pool effects and local public debt in amalgamated municipalities, Public Choice No. 183 (2020).

Gliniecka, J., Mironova, S.: The sources of financing local government in Poland and Russia: Comparative analysis. Gdansk: Gdańsk University Press, 2019.

Haug, P., Illy, A.: Größe ist nicht alles - Die Effizienz der kommunalen Leistungserstellung am Beispiel Sachsen-Anhalts (Size is not everything - The efficiency of municipal service provision using the example of Saxony-Anhalt), Wirtschaft im Wandel (The changing economy) No. 17 (2011).

Kail, Ya.: Optimizatsiya kolichestva munitsipal'nykh obrazovaniy v Rossiyskoy Federatsii: sostoyaniye, problemy, perspektivy (Optimization of the number of municipalities in the Russian Federation: state, problems, prospects), Natsional'nyye interesy: prioritety i bezopasnost' (National interests: priorities and security) No. 18 (2013).

Kosinsky, P.: Preobrazovaniye munitsipal'nykh obrazovaniy kak sposob vyravnivaniya byudzhetnoy obespechennosti (Transformation of municipalities as a way to equalize budgetary security), Munitsipal'naya sluzhba: pravovyye voprosy (Municipal Service: Legal Issues) No. 2 (2015).

Kuhlmann, S., Seyfried, M., Siegel, J. Wirkungen von Gebietsreformen: Gutachten im Auftrag des Ministeriums des Inneren und für Kommunales des Landes Brandenburg. Stand der 
Forschung und Empfehlungen für das Land Brandenburg (Effects of area reforms: Expert opinion commissioned by the Ministry of the Interior and for municipalities in the State of Brandenburg. State of research and recommendations for the state of Brandenburg). Potsdam, 2017.

Larichev, A.: Korporativnaya model' mestnogo samoupravleniya: genezis, opyt realizatsii na primere Kanady i yego primenimost' $v$ rossiyskikh usloviyakh (Corporate model of local self-government: genesis, implementation experience on the example of Canada and its applicability in Russian conditions): dissertation. Moscow, 2018.

Leontieva, A., Vinogradova, M., Shumilov, M., Kekkonen, A. Sovremennyye vyzovy razvitiyu mestnogo samoupravleniya $\vee$ Rossii i Norvegii (Modern challenges to the development of local selfgovernment in Russia and Norway), Upravlencheskoye konsul'tirovaniye (Management Consulting) No. 3 (2016).

Markvart, E., Franzke, J.: Territorial'noye reformirovaniye mestnogo samoupravleniya v Germanii i Rossii na sovremennom etape (Territorial reform of local government in Germany and Russia at the present stage), Prostranstvennaya ekonomika (Spatial Economics) No. 3 (2017).

Mironova, S.: Fiscal Lawmaking Municipalities: The Experience of Russia And European States in: Tax Sovereignty and the Concept of Fiscal Rule-Making in the Countries of Central and Eastern Europe: Conference Proceedings / Marina Sentsova (Karaseva), Eugeniusz Ruskowski, Aleksei Paul, Michal Radvan (eds.). Voronezh: Voronezh State University, Faculty of Law, 2018.

Mironova, S.: Garantii kak element finansovo-pravovogo statusa munitsipal'nykh obrazovaniy (Guarantees as an element of the financial and legal status of municipalities), Vestnik Sibirskoy akademii prava, ekonomiki i upravleniya (Bulletin of the Siberian Academy of Law, Economics and Management) No. 2 (2012).

Morozova, O.: Finansovoye vyravnivaniye i yego printsipy v byudzhetnom zakonodatel'stve Germanii (Financial equalization and its principles in the budget legislation of Germany), Aktual'nyye problemy rossiyskogo prava (Relevant problems of Russian law) No. 10 (2016).

Municipal Tax Authorities: are Changes Needed? in: Mrkývka P., Gliniecka J., Tomášková E., Juchniewicz E., Sowiński T., Radvan M. (eds.), The challenges of local government financing in the light of European Union regional policy. Conference Proceedings. Brno: Publications of the Masaryk University, Theoretical Series, Edition Scientia, 2018.

Peshkova, H.: Byudzhetnoye ustroystvo gosudarstva (rossiyskaya pravovaya kontseptsiya) (The budget structure of the state (Russian legal concept)): dissertation. Moscow, 2014.

Reingewertz, Ya.: Do Municipal Amalgamations Work? Evidence from Municipalities in Israel, Journal of Urban Economics August (2010).

Rösel, F.: Sparen Gebietsreformen Geld? - Ein Überblick über aktuelle Studien (Do territorial reforms save money? - An overview of current studies), AKADEMIE ONLINE (ACADEMY ONLINE) No. 2 (2017).

Sheveleva, N.: Byudzhetnoye vyravnivaniye $v$ Rossii kak sposob garmonizatsii mezhbyudzhetnykh otnosheniy (2000-2015) (Budget equalization in Russia as a way to harmonize intergovernmental relations (2000-2015)), Sravnitel'noye konstitutsionnoye obozreniye (Comparative constitutional review) No. 2 (2015).

Tavares, A.: Municipal Amalgamations and Their Effects: A Literature Review, Miscellanea Geographica (December 2018). 
Uksusov, V.: Munitsipal'noye obrazovaniye kak sub"yekt finansovogo prava (Municipal formation as a subject of financial law): dissertation. Moscow, 2016.

Vasyanina, E.: Teoreticheskiye osnovy pravovogo regulirovaniya publichnykh dokhodov $v$ Rossiyskoy Federatsii (Theoretical Foundations of the Legal Regulation of Public Revenues in the Russian Federation): dissertation. Moscow, 2016. 